\title{
Characterization of titanium surfaces for dental implants with inorganic contaminant
}

\section{Caracterização de superfícies de titânio para implantes dentários com contaminante inorgânico}

\author{
Marilia Garcia Diniz* \\ Marco Antonio Santos Pinheiro* \\ Antonio Carlos Canabarro Andrade Junior** \\ Ricardo Guimarães Fischer***
}

\begin{abstract}
The aim of this research was to characterize titanium surfaces blasted with aluminum oxide $\left(\mathrm{Al}_{2} \mathrm{O}_{3}\right)$ particles using the KS 400 digital image processing program. Samples of grade II titanium plates were submitted to blasting processes using particles of $\mathrm{Al}_{2} \mathrm{O}_{3}$, and treated with a hydrofluoric acid-based solution. Three digital images from each sample surface were obtained using Scanning Electron Microscopy, and half-quantitative chemical analyses were subsequently performed using Electron Dispersive Spectroscopy (EDS). In addition, parameters related to the alumina phase, such as the concentration level, the area and perimeter of the particles and their circular form factor were measured using KS 400. The mechanical/chemical treatment caused depressions up to $10 \mu \mathrm{m}$ on homogeneous surfaces. Although the chemical attack significantly removed the alumina phase, residual particles could still be identified by the EDS. The average area occupied by the alumina phase on the samples surfaces was $469.32( \pm 284.98) \mu \mathrm{m}^{2}$, the particle average perimeter was $81.61( \pm 27.68) \mu \mathrm{m}$, and the mean circular form factor was $0.60( \pm 0.05)$. Characterizing the titanium surface is essential in the evaluation of the material manufacturing process because the presence of residual aluminum particles may have deleterious effects on the formation of the osseous/implant tissue.
\end{abstract}

DESCRIPTORS: Titanium; Dental implants; Aluminum oxide; Image processing, computer-assisted.

\begin{abstract}
RESUMO: O objetivo deste trabalho foi caracterizar parâmetros relativos a superficies de titânio submetidas a jateamento com partículas de óxido de alumínio (alumina - $\mathrm{Al}_{2} \mathrm{O}_{3}$ ) por meio de análise e processamento digital de imagem no programa KS 400 (Carl Zeiss, Oberkochen, Alemanha). Amostras de titânio grau 2 foram jateadas com $\mathrm{Al}_{2} \mathrm{O}_{3}$ e submetidas a tratamento químico com soluções à base de ácido fluorídrico. Três imagens digitais das superfícies de amostras distintas foram obtidas em microscópio eletrônico de varredura. Análises químicas foram realizadas por espectroscopia por dispersão de energia (EDS). As imagens foram analisadas e processadas no KS 400 para a obtenção de parâmetros digitais e quantificação da fase residual da alumina, tais como área, perímetro das partículas e fator de forma circular. O tratamento mecânico/químico promoveu crateras de até $10 \mu \mathrm{m}$ em uma superfície homogênea em relação ao controle (tratamento somente mecânico). O ataque químico removeu de maneira significativa a alumina, porém partículas residuais foram identificadas pela EDS. A área total ocupada pela alumina nas amostras experimentais foi de 469,32 $( \pm 284,98) \mu \mathrm{m}^{2}$. O perímetro médio das partículas foi de 81,61 $( \pm 27,68) \mu \mathrm{m}$ e a média do fator de forma circular foi $0,60( \pm 0,05)$. A quantificação e caracterização da superficie do titânio são fundamentais para a avaliação da fabricação dos implantes, pois a presença de alumínio residual pode provocar efeitos deletérios na formação tecidual osso/implante.
\end{abstract}

DESCRITORES: Titânio; Implantes dentários; Óxido de alumínio; Análise de imagem assistida por computador.

\section{INTRODUCTION}

The superficial characteristics of titanium have an already known influence on the formation of the implant/bone interface ${ }^{4,10}$. Endosseous implants are usually manufactured using either commercially pure titanium or a Ti-Al-V alloy.
Studies indicated that Ti and Ti alloy are suitable, biologically compatible materials for fabrication of dental implants ${ }^{6}$. Titanium alloys with maximum tensile strength around $900 \mathrm{MPa}$ under annealing conditions are mostly used in implants of diam-

\footnotetext{
*Adjunct Professors, Department of Mechanical Engineering; **Assistant Professor, School of Dentistry; ***Full Professor, School of Dentistry - State University of Rio de Janeiro.
} 
Diniz MG, Pinheiro MAS, Andrade Junior ACC, Fischer RG. Characterization of titanium surfaces for dental implants with inorganic contaminant. Braz Oral Res 2005;19(2):106-11.

eter smaller than $4 \mathrm{~mm}$ in order to preserve the material's mechanical strength.

Biological response to artificial biomaterials is strongly regulated by the composition and properties of the implant's surface. Thus, one can modulate the biological response by modifying the implant's surface characteristics ${ }^{9,12}$.

In order to speed up or to improve the interaction between the bone and the implant, endosseous implants usually receive a surface treatment, which can be done in different ways, such as by using bioactive ceramic to cover the titanium $^{7}$. Hydroxyapatite (HA), a calcium phosphate $\left[\mathrm{Ca}_{10}\left(\mathrm{PO}_{4}\right)_{6}(\mathrm{OH})_{2}\right]$ with a mineral phase similar to that of the human bone, is a largely used ceramictype material. Covering implants with HA helps to establish a chemical link with the bone, at least at the beginning of the osseointegration process ${ }^{11,15}$. Another option involves roughening the surface of the implant, allowing for an additional restriction movement of the implant over the bone. The rough surface topography can be achieved by a blasting process with abrasive oxides, followed or not by chemical treatment using either acid or basic solu-

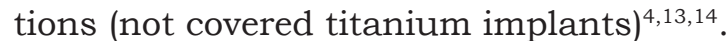

It has been proposed that superficial roughness is helpful in the initial stages of cellular adhesion, which occurs during the healing process of the osseointegration. An increased surface area may be important to enhance the expression of the osteoblast phenotype ${ }^{8}$. In addition, it may enhance, during the production of some specific proteins, the performance of hormones and other factors related to bone cell growth ${ }^{7}$.

The influence of the superficial characteristics of implants over osteoblasts depends on the maturity of the cells (in vitro) and on whether the implant surface allows cellular movement (in vivo). The superficial roughness of implants can, thereby, speed up or slow down cell growth, depending on the stage of the osseointegration process ${ }^{8}$.

The ideal topography for obtaining a good implant remains unknown ${ }^{3}$. Monitoring the evolution of surfaces throughout cellular development is necessary in order to determine the influence of microtopography.

Surface cleanliness of the titanium implant is essential for the formation of bone tissue covering the implant. The presence of elements such as fluorine, iron, and aluminum may contaminate the surface of titanium, affecting the healing proc- ess. Alternatively, aluminum contamination may occur as a result of the blasting processes using aluminum oxide $\left(\mathrm{Al}_{2} \mathrm{O}_{3}\right)$. Although this low cost procedure allows effective modification of the microtopography of the original titanium surface, the resulting aluminum residues are extremely difficult to be removed, if not practically impossible.

In the present study, digital image processing was used to quantify and to create parameters related to the presence of residual $\mathrm{Al}_{2} \mathrm{O}_{3}$ on the surface of titanium blasted using aluminum trioxide.

\section{MATERIAL AND METHODS}

Grade II titanium plates (ASTM B265-58T) submitted to mechanical and chemical treatment were used to reproduce implant surfaces. The titanium plates were submitted to blasting processes using particles of aluminum oxide $\left(\mathrm{Al}_{2} \mathrm{O}_{3}\right)$ with average diameter of $65 \mu \mathrm{m}$ and direct pressure of $138 \mathrm{kPa}$. Three plates were cut into $20 \times 20 \mathrm{~mm}$ square samples and cleaned by ultrasonic bath, followed by a hydrofluoric acid-based solution (HF) treatment. The treatment process was done in two different stages: the first using a solution of $4 \% \mathrm{HF}$ during 60 seconds and the second using a solution of both $4 \% \mathrm{HF}$ and $8 \% \mathrm{H}_{2} \mathrm{O}_{2}$ during 15 seconds. Both stages were performed at room temperature under an exhaustion system. Three digital images from each sample surface were obtained and half-quantitative chemical analyses were performed using Scanning Electron Microscopy (SEM) (JEOL JSM 6301F, Peabody, MA, USA) and Electron Dispersive Spectroscopy (EDS) (Voyager XRMA System, Noran Instruments, Madison, WI, USA). In addition, parameters related to the alumina phase such as the concentration level, the area and perimeter of all the particles and their circular form factor were measured using the KS 400 image processing program (Carl Zeiss, Oberkochen, Germany). After adjusting the brightness and contrast levels of the images, processes of segmentation, post-processing and quantification were performed.

Student's $t$-test was used for statistical analyses, and 95\% confidence intervals were considered $(\mathrm{p}<0.05)$. 
Diniz MG, Pinheiro MAS, Andrade Junior ACC, Fischer RG. Characterization of titanium surfaces for dental implants with inorganic contaminant. Braz Oral Res 2005;19(2):106-11.

\section{RESULTS}

The surfaces treated with hydrofluoric acidbased chemicals showed morphological differences. Two cases of alumina-based blasted surfaces were studied: with and without posterior chemical attack using HF. After the chemical treatment, the surfaces showed a smoother, more homogeneous and more regular microtopography. Without the chemical attack, the surfaces showed irregularities, including peaks and depressions. Figure 1 shows the morphology of one of the samples after abrasive blasting treatment using alumina followed by hydrofluoric acid attack. The presence of small pits not larger than 10 micrometers in diameter may be observed throughout the surface of titanium. Although the acid treatment was effective in modifying the surface morphology and also in removing a large amount of aluminum from the blasting process, alumina residues were identified in the EDS analysis. These incrusted particles were also observed as darker regions in the MEV analysis (Figure 1: BSE mode - backscattered electrons).

The digital images of the surfaces were processed using the KS 400 program (Carl Zeiss, Oberkochen, Germany) through a typical sequence of procedures related to analysis and digital processing of images. The processing of images is based on mathematical operations capable of modifying the values of the image's pixels, with the objective of preparing them to be analyzed by the computer; in other words, identifying image attributes that can be related either to the manufacturing processes or to the material characteristics. The following procedures were followed in order to process and analyze the images: digital imaging (MEV); adjusting of the brightness and identification of the $\mathrm{Al}_{2} \mathrm{O}_{3}$ particles; after-processing (fulfilling of emptiness, corrections of the grain boundaries); definition of attributes that allowed measurement of the average area, perimeter, and circular form factor of the particles. Figure 2 shows a surface presenting variation of brightness in its diagonal axis, enhanced by a mask of colors. The variation in the image indicates a difference in the intensity of its pixels. Problems of brightness are corrected mathematically during an intermediate step in the image processing operations.

Figure 3 presents the image shown in Figure 1 after being processed and analyzed. The mean area,

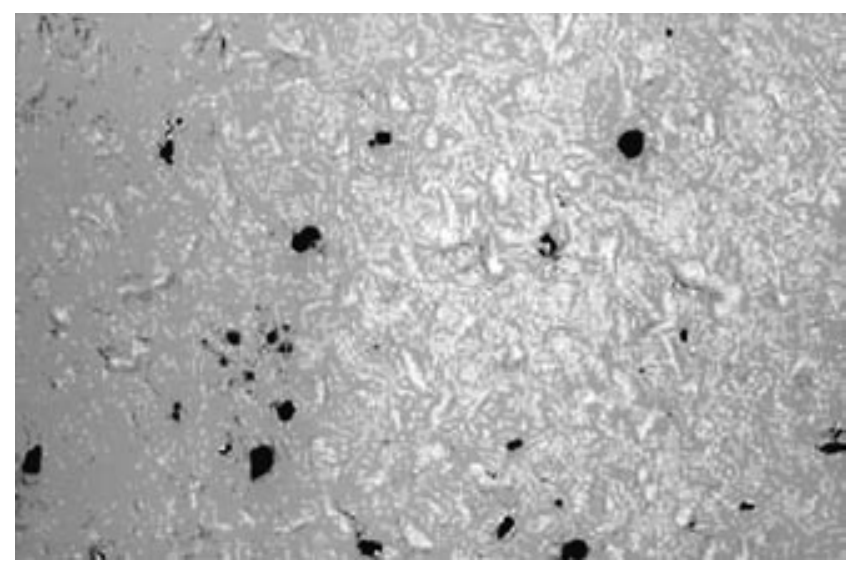

FIGURE 1 - MEV image, mode BSE, $200 \mathrm{X}$. The morphology of the surface of one of the samples after abrasive blasting treatment using alumina followed by hydrofluoric acid treatment.

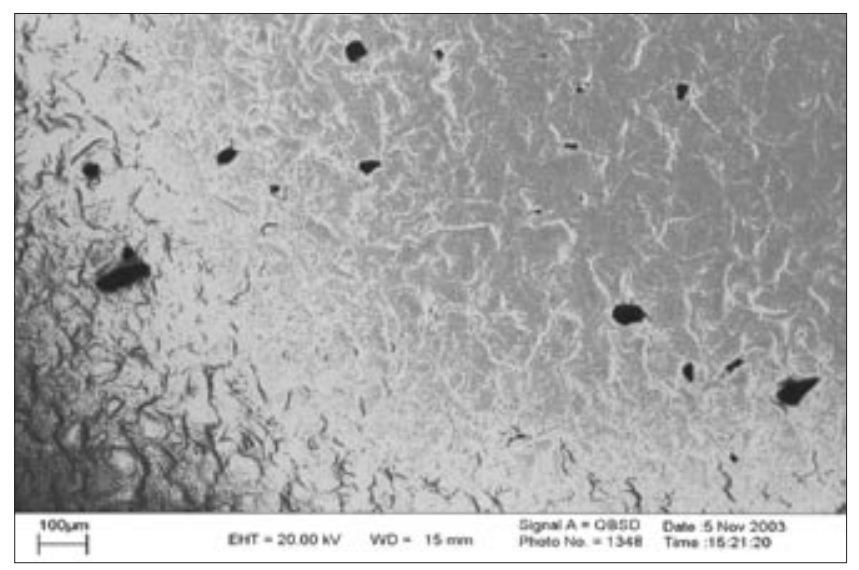

FIGURE 2 - MEV image, mode BSE, $200 \mathrm{X}$. The variation in the image is related to the difference in brightness. Brightness adjustment is done during the preprocessing phase.

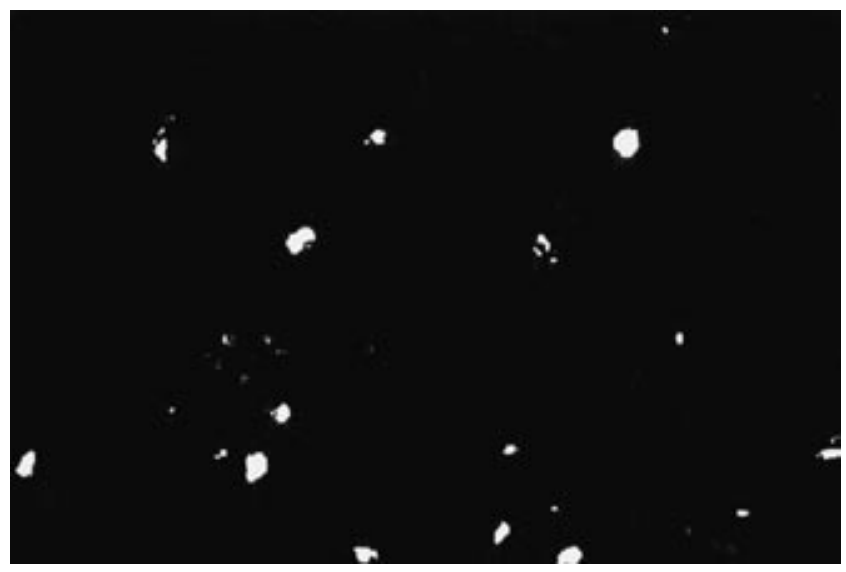

FIGURE 3 - Image obtained after processing of the digital image, $200 \mathrm{X}$. Total area is equal to $1.903 \times 10^{6} \mu \mathrm{m}^{2}$. The $\mathrm{Al}_{2} \mathrm{O}_{3}$ particles (clear spots) occupy $1.3 \times 10^{4} \mu \mathrm{m}^{2}$ $(0.7 \%)$. 
Diniz MG, Pinheiro MAS, Andrade Junior ACC, Fischer RG. Characterization of titanium surfaces for dental implants with inorganic contaminant. Braz Oral Res 2005;19(2):106-11.

TABLE 1 - Average area, perimeter and circular form factor for three different samples.

\begin{tabular}{c|c|c|c}
\hline \hline Images & Area $( \pm \mathrm{SD}) \mathrm{Ns}$ & Perimeter $( \pm \mathrm{SD}) \mathrm{Ns}$ & Circular form factor \pm SD) Ns \\
\hline 1 & $537.608 \mu \mathrm{m}^{2} \pm 307.411$ & $85.491 \mu \mathrm{m} \pm 26.178$ & $0.639 \pm 0.059$ \\
\hline 2 & $542.810 \mu \mathrm{m}^{2} \pm 386.594$ & $88.006 \mu \mathrm{m} \pm 37.629$ & $0.589 \pm 0.059$ \\
\hline 3 & $327.577 \mu \mathrm{m}^{2} \pm 160.955$ & $71.349 \mu \mathrm{m} \pm 19.278$ & $0.608 \pm 0.065$ \\
\hline \hline
\end{tabular}

Ns: non-significant. SD: standard deviation.

perimeter and circular form of the $\mathrm{Al}_{2} \mathrm{O}_{3}$ particles were calculated digitally.

It was necessary to process the pixel changes using mathematical operations in several intermediate images. Aside from Figure 2, these intermediate images are not shown in the present work.

Table 1 shows the average area, perimeter and circular form factor of the three analyzed images from the three different prepared samples.

Form factors are used to identify specific forms in digital images. Normally, they are defined by a value that varies between 0 and 1, assuming a maximum value for objects with specific geometric forms, such as perfectly spherical forms. Specifically, circular form factors can be based on particle areas.

\section{DISCUSSION}

The role of surface contamination in implant failures is not yet well understood ${ }^{10}$. Since blasting processes are abrasive, they can not only modify the surface roughness ${ }^{13}$ but also remove contaminants resting on the metallic surface of the implant, making the surface more reactive ${ }^{16}$. It is possible that the use of abrasive particles whose chemical composition differs from the chemical composition of the implant may alter the biocompatibility of the implant's surface ${ }^{16}$. It has been suggested that the presence of inorganic contaminants could lead to lack of clinical success. Aluminum ions are suspected to impair bone formation by a possible competitive action with calcium ${ }^{1}$. Titanium implant casting associated with tissue breakdown has revealed embedded particles of alumina ${ }^{2}$.

Specific surface chemical treatments have been used for removing contaminants originating from either the implant's manufacturing processes or the clinical surgical preparation. These treatments involve the use of solutions such as hydrofluoric acid ( $\mathrm{HF})$, sulfuric acid $\left(\mathrm{H}_{2} \mathrm{SO}_{4}\right)$, nitric acid $\left(\mathrm{HNO}_{3}\right)$, phosphoric acid $\left(\mathrm{H}_{3} \mathrm{PO}_{4}\right)$, and organic acids, as well as methods utilizing anodic oxida- tion with electric current in acid environment and nitretation techniques ${ }^{5}$.

In the present research, digital image processing was used to quantify and create parameters related to the presence of residual $\mathrm{Al}_{2} \mathrm{O}_{3}$ on the surface of titanium blasted using aluminum oxide. The surfaces treated with hydrofluoric acid-based chemicals showed important morphological differences. After the chemical treatment, the surfaces showed a smoother, homogeneous and more regular microtopography, whereas without the chemical treatment the surfaces showed irregularities, including peaks and depressions. Although the acid treatment was effective in both modifying the surface morphology and in removing a large amount of aluminum from the blasting process ${ }^{4}$, alumina residues were identified in the EDS. These incrusted particles were also observed as darker regions in the MEV (BSE mode - backscattered electrons - Figures 1 and 2).

Figure 3 presents the image shown in Figure 1 after being processed and analyzed by KS 400 (Carl Zeiss, Oberkochen, Germany), which is a versatile image processing program designed to support demanding professional applications. The KS 400 program offers a wide range of different parameters for measurement and analysis. The area, perimeter and circular form of the $\mathrm{Al}_{2} \mathrm{O}_{3}$ particles were calculated digitally (Table 1 ). The results showed that the total contaminant particle area (depicted as clear regions in Figure 3) was of similar size for all samples. The area parameter of the individual particle showed higher dispersion of the distribution of values. For example, $\mathrm{Al}_{2} \mathrm{O}_{3}$ particles as large as $50 \mu \mathrm{m}$ were mixed with very small ones, resulting in a high variation in the size of the particles $\left(537.608 \mu \mathrm{m}^{2} \pm 307.411 ; 542.81 \mu \mathrm{m}^{2} \pm 386.594\right.$ and $327.577 \mu \mathrm{m}^{2} \pm 160.955$, respectively, for the three images), and consequently in larger standard deviations. The mean area occupied by the aluminum oxide on the sample surfaces was 469.32 $( \pm 284.98) \mu \mathrm{m}^{2}(0.7 \%$ of the total area).

The perimeter parameter depends on both the morphology and the size of the particles of $\mathrm{Al}_{2} \mathrm{O}_{3}$. 
Diniz MG, Pinheiro MAS, Andrade Junior ACC, Fischer RG. Characterization of titanium surfaces for dental implants with inorganic contaminant. Braz Oral Res 2005;19(2):106-11.

Consequently, results for the three processed images showed significant dispersion of measured values $(85.491 \mu \mathrm{m} \pm 26.178 ; 88.006 \mu \mathrm{m} \pm 37.629$ and $71.349 \mu \mathrm{m} \pm 19.278)$. The particle average perimeter was $81.61 \mu \mathrm{m}$.

The obtained values for the circular factor for the $\mathrm{Al}_{2} \mathrm{O}_{3}$ particles approximate a spherical form $(0.639 \pm 0.059 ; 0.589 \pm 0.059$ and $0.608 \pm 0.065)$. The obtained circular factors are likely to be a common characteristic of all titanium surfaces blasted with $\mathrm{Al}_{2} \mathrm{O}_{3}$ particles, suggesting that the studied manufacturing process resulted in contaminated particles of regular and soft geometry, which tend to be spherical in form. The mean circular form factor was $0.60( \pm 0.05)$.

Table 1 shows only the results related to the average values of area, perimeter and circular form factor related to the contaminant particles found in the three different samples. Differences in the measurements across distinct sample families were not calculated (analysis of variance). Although the results obtained in this study may not be extrapolated due to the small number of samples (or images) here utilized, we proposed a fast and accurate method for the analysis and processing of the digital images which may be employed in a considerable number of similar cases. The number of samples and images were reduced due to the high cost of the microscopy technology utilized in this study.

\section{REFERENCES}

1. Bushinsky DA, Sprague SM, Hallegot P, Girod C, Chabala JM, Levi-Setti R. Effects of aluminum on bone surface ion composition. J Bone Miner Res 1995;10:1988-97.

2. Darvell BW, Samman N, Luk WK, Clark RKF, Tideman H. Contamination of titanium castings by aluminum oxide blasting. J Dent 1995;23:319-22.

3. Degasne I, Basle MF, Demais V, Hure G, Lesourd M, Grolleau B, et al. Effects of roughness, fibronectin and vitronectin on attachment, spreading and proliferation of human osteoblast-like cells (Saos-2) on titanium surfaces. Calcif Tissue Int 1999;64:499-507.

4. Diniz MG, Soares GA, Coelho MJ, Fernandes MH. Surface topography modulates the osteogenesis in human bone marrow cell cultures grown on titanium samples prepared by a combination of mechanical and acid treatments. $J$ Mater Sci Mater Med 2002;13:421-32.

5. Kawahara H. Biomaterials for Dental Implants. In: Wise DL. Encyclopedic Handbook of Biomaterials and Bioengineering. Part B, v. 2. New York: Marcel Dekker; 1995. p. $1469-524$.

\section{CONCLUSIONS}

Using digital image processing, it was possible to accurately quantify and create parameters related to the presence of the $\mathrm{Al}_{2} \mathrm{O}_{3}$ phase, suggesting that this is an effective and appropriated process to characterize biomaterial-manufacturing processes. In spite of the difficulties related to the processing of digital images caused by the presence of "noises" as well as by low contrast level, the results obtained were significantly positive in characterizing the material.

Once a convenient sequence for the processing steps is defined, the sequence can be repeated for all images, creating a computational routine that makes for an easier processing of multiple images. After correctly performing the segmentation process, several attributes, such as the contaminant area, perimeter, principal dimensions, as well as form factor could be easily determined. Quantifying and characterizing the titanium surface is essential in both the evaluation of the material manufacturing process and its influence on the biological behavior of osteoblastic cell cultures.

\section{ACKNOWLEDGMENT}

The authors thank Prof. Sidnei Paciornick, (Pontifical Catholic University of Rio de Janeiro, Brazil) for his contribution in this study.

6. Keller JC, Stanford CM, Wightman JP, Draughn RA, Zaharias R. Characterizations of titanium implant surfaces. J Biomed Mater Res 1994;28:939-46.

7. Martin JY, Schwartz Z, Hummert TW, Schraub DM, Simpson J, Lankford J, et al. Effect of titanium surface roughness on proliferation, differentiation, and protein synthesis of human osteoblast-like cells (MG63). J Biomed Mater Res 1995;29:389-401.

8. Ong JL, Carnes DL, Cardenas HL, Cavin R. Surface roughness of titanium on bone morphogenetic protein-2 treated osteoblast cells in vitro. Implant Dent 1997;6:19-24.

9. Ong JL, Prince CW, Lucas LC. Cellular response to wellcharacterized calcium phosphate coatings and titanium surfaces in vitro. J Biomed Mater Res 1995;29:165-72.

10. Piattelli A, Degidi M, Paolantonio M, Mangano C, Scarano A. Residual aluminum oxide on the surface of titanium implants has no effect on osseointegration. Biomaterials 2003;24:4081-9.

11. Prado-da-Silva MH. Recobrimento de Titânio com HA: Desenvolvimento do Processo de Deposição Eletrolítica e Caracterização Biológica in vitro [Tese de Doutorado]. Rio de 
Diniz MG, Pinheiro MAS, Andrade Junior ACC, Fischer RG. Characterization of titanium surfaces for dental implants with inorganic contaminant. Braz Oral Res 2005;19(2):106-11.

Janeiro: Instituto Alberto Luiz Coimbra de Pós-Graduação e Pesquisa de Engenharia da UFRJ; 1999.

12. Ratner BD, Hoffman AS, Schoen FJ, Lemons JE. Biomaterials Science: an Introduction to Materials in Medicine. California: Academic Press; 1996.

13. Taborelli M, Jobin M, François P, Vaudaux P, Tonetti $\mathrm{M}$, Szmukler-Moncler S, et al. Influence of surface treatments developed for oral implants on the physical and biological properties of titanium. (I) Surface Characterization. Clin Oral Implants Res 1997;8:208-16.
14. Takeuchi M, Abe Y, Yoshida Y, Nakayama Y, Okazaki M, Akagawa Y. Acid pretreatment of titanium implants. Biomaterials 2003;24:1821-7.

15. Vidigal GM Jr, Aragones LC, Campos A Jr, Groisman M. Histomorphometric Analyses of Hydroxyapatite-Coated and Uncoated Titanium Dental Implants in Rabbit Cortical Bone. Implant Dent 1999;8:295-302.

16. Wennerberg A, Albrektsson T, Johansson C, Andersson B. Experimental study of turned and grit-blasted screw-shaped implants with special emphasis on effects of blasting material and surface topography. Biomaterials 1996; 17:15-22.

Received for publication on Jul 29, 2004

Sent for alterations on Dec 15, 2004 Accepted for publication on May 12, 2005 